\title{
Oxidation stability of boride coatings
}

\author{
J. Ptačinová*, M. Drienovský, M. Palcut, R. Čička, M. Kusý, M. Hudáková
}

\author{
Slovak University of Technology in Bratislava, Faculty of Materials Science and Technology in Trnava, \\ Institute of Materials Science, Paulinska 16, 91724 Trnava, Slovak Republic
}

Received 22 October 2014, received in revised form 25 November 2014, accepted 4 December 2014

\begin{abstract}
In this work, plain, low carbon steel S235JRG1 was boronized at $1273 \mathrm{~K}$ for $45-150 \mathrm{~min}$ by using a Durborid ${ }^{\circledR}$ powder. The microstructure, phase constitution and oxidation behavior of the resulting boride layers have been investigated. Layers with an average thickness of 76$123 \mu \mathrm{m}$ have been produced. The boride layer has a distinct tooth-like microstructure. It is composed of $\mathrm{Fe}_{2} \mathrm{~B}$ and $\mathrm{FeB}$ in unequal amounts. The boride layer oxidation behavior has been investigated by a simultaneous thermal analysis in a flowing synthetic air at 873-1173 K for 21$24 \mathrm{~h}$. A parabolic oxidation of the boride layer has been observed. The rate constants are found between $1.039 \times 10^{-9}$ to $3.781 \times 10^{-6} \mathrm{~kg}^{2} \mathrm{~m}^{-4} \mathrm{~s}^{-1}$, depending on temperature and oxidation time. The activation energy of oxidation at temperatures below $1173 \mathrm{~K}$ has been estimated to be $93 \mathrm{~kJ} \mathrm{~mol}^{-1}$. At $1173 \mathrm{~K}$, two successive parabolic periods have been found, followed by a breakaway oxidation behavior. The oxide scale of the boronized steel is composed of different iron oxides and iron borates. The oxidation mechanisms of boride coatings are discussed and implications towards high temperature stability are provided.
\end{abstract}

K e y w o r d s: boronizing, high temperature oxidation, X-ray diffraction, thermogravimetric analysis

\section{Introduction}

Boronizing (boriding) is a thermo-chemical surface treatment method in which boron atoms diffuse into a metal substrate and form a metal boride layer on the surface. During this process, temperatures of $973-1273 \mathrm{~K}$ and processing times of $1-$ $10 \mathrm{~h}$ are typically used [1-3]. Since boron is a relatively small size element, it easily diffuses into a variety of metals, including $\mathrm{Fe}$ and Co-based alloys and refractory materials [4-8]. The resulting boride layers are characterized by high hardness, good wear, heat and corrosion resistance. The boronized ferrous alloys, for example, have substantially higher hardness compared to carburized or nitrided steels [9]. The boronized steels have an excellent wear resistance [10-14]. Furthermore, these materials exhibit a good resistance to chemical attack by molten metals, nonoxidizing acids, alkaline and saline solutions [15-18]. Industrial applications of boronized steel include drive shafts, camshafts, pulleys, machine slide-ways, tanks, weapons and some parts for agricultural machinery [19].

According to the Fe-B phase diagram, boron forms two different iron borides, $\mathrm{FeB}$ and $\mathrm{Fe}_{2} \mathrm{~B}$ [1]. The boronizing of ferrous materials results in the formation of either single phase or double phase iron boride layer with definite composition. The phase formation depends on boron concentration, alloy chemical composition, temperature, processing time and boronizing method [20]. Single-phase $\mathrm{Fe}_{2} \mathrm{~B}$ layers are preferred since $\mathrm{Fe}_{2} \mathrm{~B}$ is less brittle compared to $\mathrm{FeB}$ and forms a surface with a high compressive stress [21, 22]. Furthermore, $\mathrm{Fe}_{2} \mathrm{~B}$ has a favorable thermal expansion coefficient. As such, it allows a subsequent heat treatment of the base metal without impairing its properties. The kinetics of boride formation is controlled by boron diffusion in $\mathrm{FeB} / \mathrm{Fe}_{2} \mathrm{~B}$ layers, respectively [2325]. The formation of a single phase $\mathrm{Fe}_{2} \mathrm{~B}$ results in a tooth-type boride layer desired for most industrial applications. This microstructure provides a significant adherence between the coating and substrate thereby

*Corresponding author: tel. +421 906068 325; e-mail address: jana.ptacinova@stuba.sk 
Table 1. Chemical composition of S235JRG1 steel (wt.\%)

\begin{tabular}{ccccccc}
\hline $\mathrm{C}$ & $\mathrm{P}$ & $\mathrm{S}$ & $\mathrm{N}$ & $\mathrm{Mn}$ & $\mathrm{Cu}$ & $\mathrm{Fe}$ \\
\hline $\max 0.17$ & max. 0.04 & max. 0.04 & 0.012 & 1.40 & max. 0.55 & Bal. \\
\hline
\end{tabular}

reducing the risk of spallation during mechanical loading.

Boride layers exhibit a superior high temperature oxidation resistance. The high temperature oxidation resistance of boride layers on $45 \#$ carbon steel was investigated by Yan et al. [26]. The authors observed that there was no boride oxidation below $1003 \mathrm{~K}$ and only a slight weight gain was detected between 1003 and $1203 \mathrm{~K}$ [26]. The transformation of $\mathrm{FeB}$ into $\mathrm{Fe}_{2} \mathrm{~B}$ was observed to take place at $1133 \mathrm{~K}$ [26]. The melting of the $\mathrm{Fe}_{2} \mathrm{~B}$ phase was observed to start at temperatures close to $1273 \mathrm{~K}$ [26].

The oxidation kinetics of boronized steel has been recently investigated by Suwattananont and Petrova [27]. For boronized steel, the oxidation resistance was higher compared to unboronized steel [27-30]. The superior oxidation resistance is mainly attributed to the formation of different iron borates and boron oxide scales, respectively [27-29]. As for 773-873 K, an amorphous $\mathrm{B}_{2} \mathrm{O}_{3}$ was observed, forming a glassy layer on the coating surface [27]. $\mathrm{B}_{2} \mathrm{O}_{3}$ has a low oxygen diffusion coefficient thereby acting as an effective oxidation barrier [27]. At $983-1073 \mathrm{~K}$, the formation of iron borate was observed [27]. A severe oxidation of iron boride layers at $1173 \mathrm{~K}$ has been reported [27], however, the underlying activation mechanisms have not yet been examined. So far, the mechanism of formation of a complex scale, consisting of both iron oxides and iron borates, has not been fully explored.

In previous studies, we have investigated the microstructure, phase constitution and microhardness of boride layers prepared by diffusion boronizing [21, 22, 31]. In the present work, we aim to investigate the high temperature oxidation behavior of boride coatings. The oxidation kinetics has been investigated at $973-1173 \mathrm{~K}$ to yield a better understanding of the protective effect of the boride coating and underlying activation mechanisms.

\section{Experimental part}

Grade steel S235JRG1 (Ferostav Trnava, Slovakia) has been used as substrate material. The chemical composition is provided in Table 1. The steel was received in a cylindrical form (diameter $12 \mathrm{~mm}$, length $2 \mathrm{~m}$ ). The steel roll was cut into $2 \mathrm{~mm}$ long cylindrical specimens. The samples were de-greased and subsequently boronized at $1273 \mathrm{~K}$ by using a powder-pack method. The samples were placed in a glass-sealed container and buried in a pre-dried

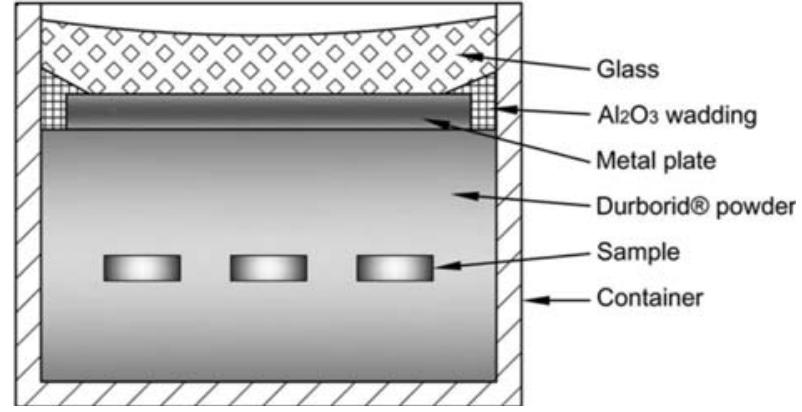

Fig. 1. Schematic of the powder-pack boronizing.

Durborid ${ }^{\circledR}$ powder mixture, which contains $\mathrm{B}_{4} \mathrm{C}$ as a boron source. The experimental set up is provided in Fig. 1. The first group of samples was heat-treated at $1273 \mathrm{~K}$ for $45 \mathrm{~min}$. The second group of samples was heat-treated at $1273 \mathrm{~K}$ for $150 \mathrm{~min}$. After boronizing, the containers were air-cooled and samples were subsequently removed.

The sample microstructures were investigated after standard sectioning, polishing and etching procedures in an optical microscope Zeiss NEOPHOT 2 equipped with a CCD camera. The boride layer thickness was analyzed by image processing software IMPOR PRO. The microhardness of the boronized layer, transient region and substrate material were measured with an Indenta Met 1100 indenter placed in a Zeiss Neophot 21 microscope by using a load of $100 \mathrm{~g}$ (HV0.1). The surface topography of the coating was studied by employing a confocal laser scanning microscope Zeiss LSM 700. The three-dimensional topographical resolution was achieved by using the ZEN 2009 software.

The thermal stability of boride layers has been investigated during linear heating in a flowing synthetic air (80 vol. $\% \mathrm{~N}_{2}, 20$ vol. $\% \mathrm{O}_{2}$ ). The air flow was kept constant at $20 \mathrm{ml} / \mathrm{min}$. The boronized steel samples were placed inside alumina crucibles and heated from room temperature to $873-1173 \mathrm{~K}$ by using heating rate of $10 \mathrm{~K} \mathrm{~min}^{-1}$. The dwell time was $21-24 \mathrm{~h}$. The mass gain of the samples was recorded on a Netzsch STA409CD simultaneous thermal analyzer.

The occurrence of the phases before and after oxidation was studied by X-ray Panalytical Empyrean PIX -Cel 3D diffractometer with Bragg-Brentano geometry (XRD), working with a CoK $\alpha 1,2$ radiation beam. The $\mathrm{X}$-ray radiation beam was generated at $40 \mathrm{kV}$ and 40 $\mathrm{mA}$. The sample diffraction patterns were collected between $20^{\circ}$ and $140^{\circ}$ (2-theta) at room temperature. 


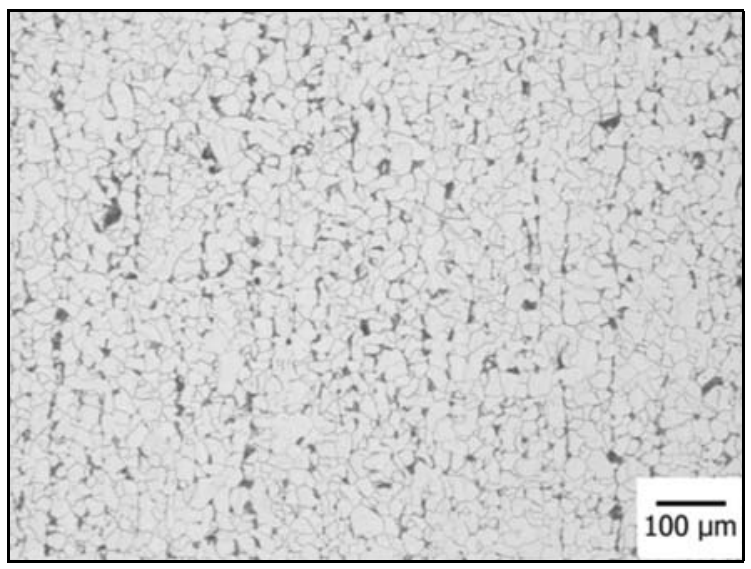

Fig. 2. Microstructure of the steel substrate.

The phase assignment was made according to the PDF database ICSD FIZ Karlsruhe 2011-1.

\section{Results and discussion}

\subsection{Microstructure and phase constitution of boride coatings}

The microstructure of the as-received steel substrate is provided in Fig. 2. The starting material is homogeneous. It has a ferritic-perlitic microstructure, typical for this kind of low carbon steel. The sample microstructures after boronizing are compared in Fig. 3. The images indicate a homogeneous boride layer has been developed on the substrate during powder-pack boronizing. The coating layer is completely covering the metal surface. The boride layer has a distinct tooth-like microstructure at the interface with the metal substrate.

The layer thicknesses, measured at different sample locations, are compared in Table 2. The layer thickness varies with boronizing time, and thicker layers have been found for steels boronized for $150 \mathrm{~min}$ (Fig. 3). The distinct tooth-type layer microstructure has been observed (Fig. 3b). The acicular type of layer microstructure is related to the preferred orientation of boron diffusion in (002) crystallographic direction [32]. This type of layer growth is typically observed for low alloy steels $[3,33]$. The presence of particular alloying elements, most importantly $\mathrm{Cr}, \mathrm{Ni}, \mathrm{Mo}$ or $\mathrm{Si}$, is known to reduce the layer thickness [3, 33]. These elements act as a diffusion barrier to boron, leading to flattening out the layer microstructure at the boride-metal substrate interface. These elements have not been present in the steel (Table 2). Mn, the major alloying element in S235JRG1 (Table 1), is less efficient in retarding the boride layer growth compared to $\mathrm{Cr}$ or $\mathrm{Ni}[3]$.

The room temperature X-ray diffraction patterns
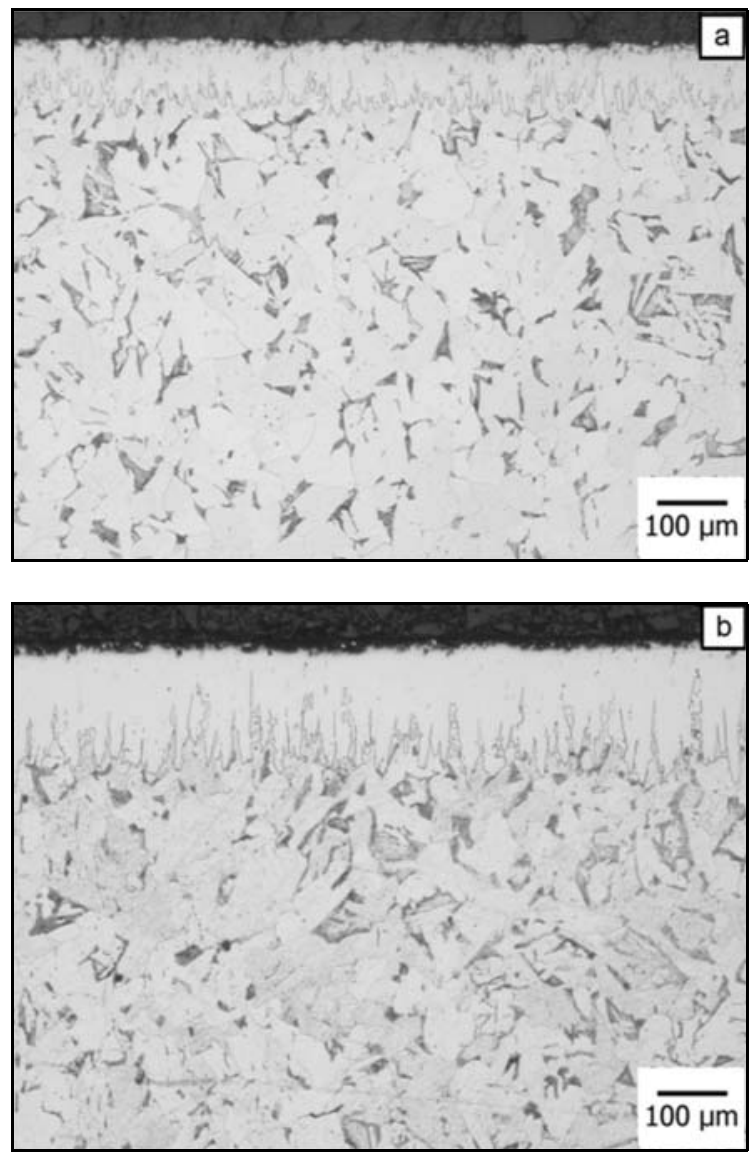

Fig. 3. Cross sectional images of samples boronized at $1273 \mathrm{~K}$ for $45 \mathrm{~min}$ (a) and $150 \mathrm{~min}(\mathrm{~b})$.

Ta ble 2. Boronized layer thickness

\begin{tabular}{lccc}
\hline & \multicolumn{3}{c}{ Layer thickness $(\mu \mathrm{m})$} \\
\cline { 2 - 4 } Boronizing parameters & Average & Minimum & Maximum \\
\hline $1273 \mathrm{~K} / 45 \mathrm{~min}$ & 76 & 39 & 113 \\
$1273 \mathrm{~K} / 150 \mathrm{~min}$ & 123 & 56 & 190 \\
\hline
\end{tabular}

of the steel samples are compared in Fig. 4. The $\mathrm{XRD}$ pattern of the as-received specimen is relatively simple, with peaks of the ferrite phase $(\alpha-\mathrm{Fe})$ easily identified (Fig. 4a).

The phase constitution of the sample after powderpack boronizing is provided in Fig. 4b. The major phase is $\mathrm{Fe}_{2} \mathrm{~B}$. Small signals of $\mathrm{FeB}$ are also observed. The XRD pattern indicates the boride coating is mainly composed of $\mathrm{Fe}_{2} \mathrm{~B}$ (Fig. 4b). The amount of $\mathrm{FeB}$ is probably minor. Signals of the ferrite phase have not been detected (Fig. 4b). This is probably related due to a limited X-ray beam penetration through the outer boride layer. 
Ta ble 3. Microhardness HV0.1 of boronized steel samples

\begin{tabular}{lllll}
\hline & \multicolumn{4}{c}{ Microhardness HV0.1 } \\
\cline { 2 - 5 } & \multicolumn{1}{c}{$1^{\text {st }}$ line } & $2^{\text {nd }}$ line & Diffusion zone & Substrate \\
\hline $1273 \mathrm{~K} / 45 \mathrm{~min}$ & $1625 \pm 8$ & $1263 \pm 12$ & $154.4 \pm 1.9$ & $138.1 \pm 1.2$ \\
$1273 \mathrm{~K} / 150 \mathrm{~min}$ & $1687 \pm 19$ & $1541 \pm 8$ & $167.0 \pm 0.9$ & $135.0 \pm 1.1$ \\
\hline
\end{tabular}
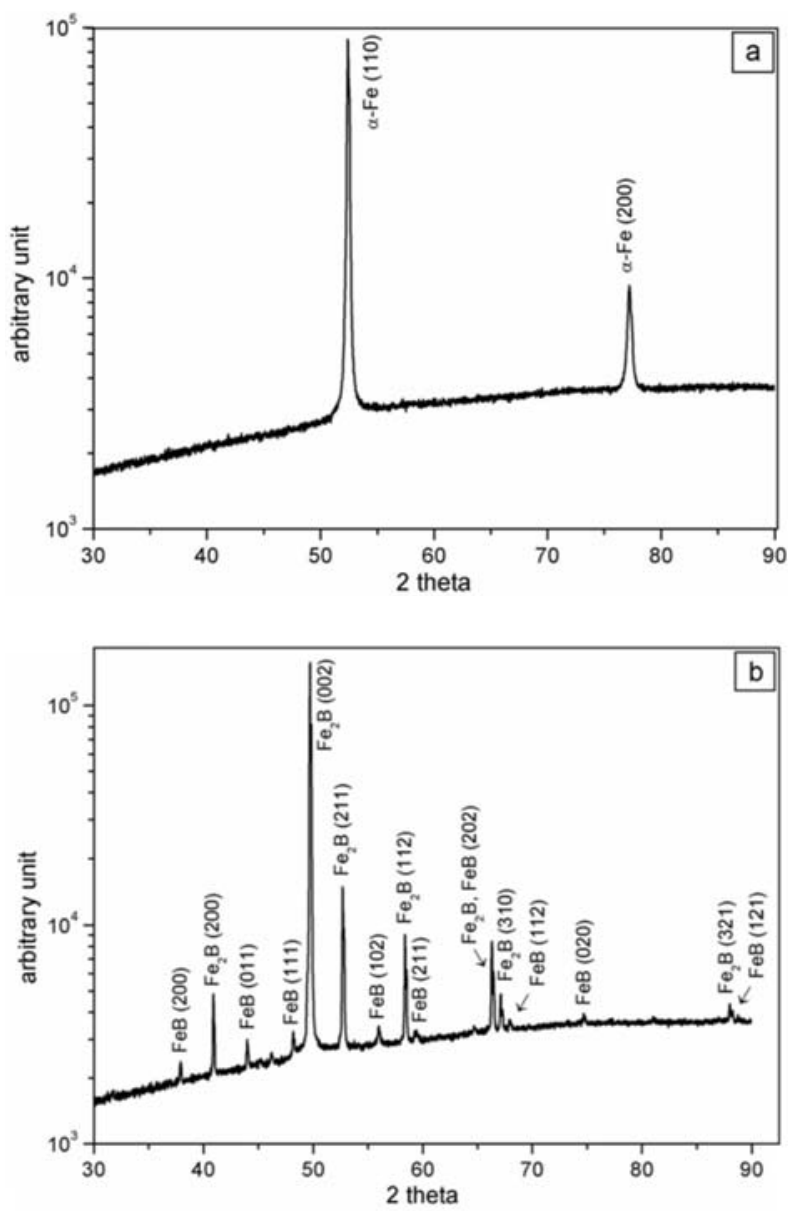

Fig. 4. Room temperature XRD patterns of the steel substrate (a) and sample boronized at $1273 \mathrm{~K}$ for $150 \mathrm{~min}$ (b).

More insight into layer chemical composition can be obtained by investigating the layer microhardness by an indentation test. Microhardness of the boride layers has been measured in different sample locations, as presented in Fig. 5. Mean values, calculated from 20 different measurements, are compared in Table 3. Also uncertainties are included. The data show that the layer microhardness is as high as 1650 HV0.1. Nearly identical values are observed for samples boronized for 45 and $150 \mathrm{~min}$, respectively. This observation indicates that similar boride compositions have been formed on the steel substrates, despite having different boronizing times.

The observed microhardness values (1650 HV0.1)

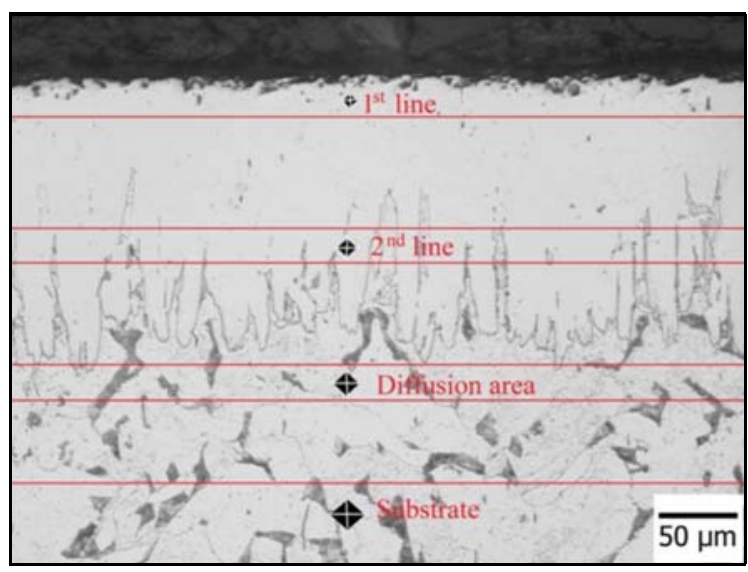

Fig. 5. Indentation locations across the coatings during Vickers microhardness test.

indicate that the boride layer is mostly composed of $\mathrm{Fe}_{2} \mathrm{~B}$. This value is approximately 10 times higher compared to the steel substrate (135 HV0.1, Table 3). The reported microhardness of $\mathrm{FeB}$ is 2000-2200 HV0.1 [20-22]. Since these values have not been observed in the present study it can be suggested that the amount of $\mathrm{FeB}$ in the boride layer was very small. The FeB layer is expected to be very thin and most of the phase is probably located on the sample surface.

The surface morphology of the boronized steel samples has been investigated by employing a confocal laser scanning microscope Zeiss LSM 700. The results are presented in Fig. 6. The surface roughness values are compared in Table 4 . The results show that the surface roughness of the material has gradually increased from $0.06 \mu \mathrm{m}$ to 0.6 and $1.1 \mu \mathrm{m}$ after boronizing. The changes in surface roughness are related to the growth of the boride layer. The surface roughness values can be used as an indication of the amount of $\mathrm{FeB}$ phase in the layer since $\mathrm{FeB}$ has a smaller density than $\mathrm{Fe}_{2} \mathrm{~B}$, because of higher volume fraction of boron [34]. The ratio between the surface roughness and layer thickness is 0.0079 and 0.0089 in the present case. These values indicate a low amount of the FeB phase in the boride layer.

During powder-pack boronizing high boron concentrations are used to increase the process efficiency [23]. The surface boron concentration has a direct influence on the layer growth of $\mathrm{FeB}$ phase. This effect is probably less pronounced for $\mathrm{Fe}_{2} \mathrm{~B}$. In order to reduce 


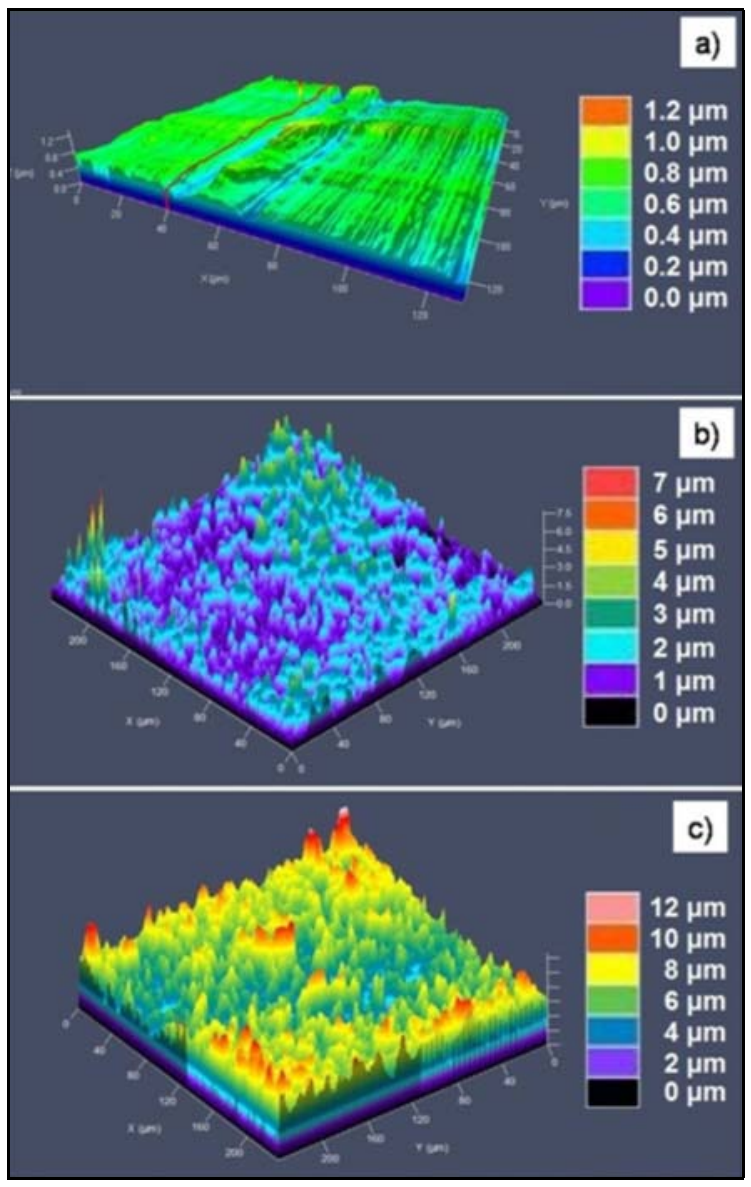

Fig. 6. Surface topography of the substrate: before boronizing (a), after boronizing at $1273 \mathrm{~K}$ for $45 \mathrm{~min}$ (b), after boronizing at $1273 \mathrm{~K}$ for $150 \mathrm{~min}(\mathrm{c})$.

Table 4. Surface roughness of unboronized and boronized steel samples

\begin{tabular}{|c|c|c|c|}
\hline \multirow{2}{*}{$\begin{array}{l}\text { Measure- } \\
\text { ment no. }\end{array}$} & \multicolumn{3}{|c|}{$R a(\mu \mathrm{m})$} \\
\hline & Substrate & $1273 \mathrm{~K} / 45 \mathrm{~min}$ & $1273 \mathrm{~K} / 150 \mathrm{~min}$ \\
\hline 1 & 0.054 & 0.547 & 1.103 \\
\hline 2 & 0.062 & 0.640 & 1.161 \\
\hline 3 & 0.059 & 0.676 & 1.118 \\
\hline Mean value & 0.058 & 0.621 & 1.127 \\
\hline
\end{tabular}

the FeB thickness the choice of an intermediate temperature is recommended. Temperature of $1273 \mathrm{~K}$ is a good choice for powder-pack boronizing since higher temperatures could increase diffusion processes and result in an increased $\mathrm{FeB} / \mathrm{Fe}_{2} \mathrm{~B}$ layer thickness ratio [23]. The results presented above show that by selecting $1273 \mathrm{~K}$ during boronizing the amount of hard and brittle $\mathrm{FeB}$ phase could be reduced to minimum.
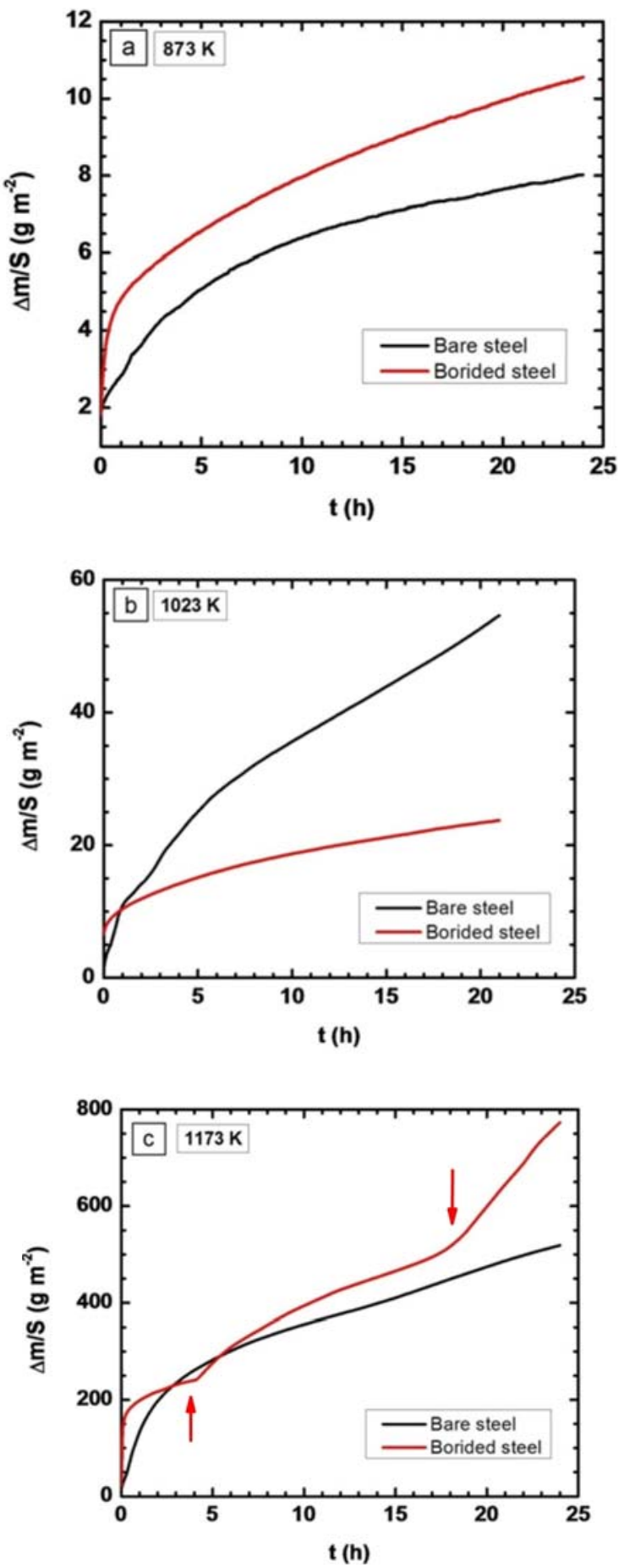

Fig. 7. Weight gain of the samples in flowing air at $873 \mathrm{~K}$ (a), $1023 \mathrm{~K}$ (b) and $1173 \mathrm{~K}$ (c).

\subsection{Oxidation stability of boride coatings}

The samples with and without boride coating were annealed at $873-1173 \mathrm{~K}$ in flowing synthetic air to study their high temperature oxidation behavior. The mass gain of the samples was recorded by thermogravimetric analysis. The kinetic results are presented in 
Fig. 7. At $873 \mathrm{~K}$ a small weight gain of the samples was observed (Fig. 7a). The data for samples with and without coating were comparable, with slightly higher mass gain recorded for the boronized steel. At $1023 \mathrm{~K}$, the weight gain of the bare steel significantly increased compared to boronized specimen (Fig. 7b). The scale formed on the boronized steel at $873-1023 \mathrm{~K}$ was adherent to the substrate. A change in the oxidation behavior has been observed at $1173 \mathrm{~K}$ (Fig. 7c). The mass gain of the boronized steel became comparable to bare steel and further increased at longer annealing times. Two kinetic transitions have been observed. They are indicated by arrows in Fig. 7c. The results indicate that the oxidation mechanism of the boride layer changes with temperature and oxidation time.

The mass gain increases with increasing oxidation time. The weight gain results presented in Fig. 7 were analyzed according to the parabolic rate law. The parabolic rate equation law is given by the following equation [35]:

$$
\left(\frac{\Delta m}{S}\right)^{2}=k_{\mathrm{p}} t+C
$$

where $\left(\frac{\Delta m}{S}\right)$ is the weight gain of the samples per unit area, $t$ is the annealing time, $C$ is the integration constant and $k_{\mathrm{p}}$ is the parabolic rate constant. The plot of the mass gain squared versus time is linear (Fig. 8a,b). The obedience of the parabolic rate law indicates that the oxidation is a diffusion-controlled process. The slope of the line represents the parabolic rate constant. The obtained parabolic rate constants are compared in Table 5 .

Parabolic rate constants increase with increasing temperature. The temperature dependence of the rate
Table 5. Experimental parabolic rate constants

\begin{tabular}{cll}
\hline \multirow{2}{*}{$T(\mathrm{~K})$} & \multicolumn{3}{c}{$k_{\mathrm{p}}\left(\mathrm{kg}^{2} \mathrm{~m}^{-4} \mathrm{~s}^{-1}\right)$} \\
\cline { 2 - 3 } & Bare steel & \multicolumn{2}{c}{ Borided steel } \\
\hline \multirow{2}{*}{873} & $4.494 \times 10^{-10}(0-7 \mathrm{~h})$ & $1.039 \times 10^{-9}$ \\
& $1.160 \times 10^{-9}(10-24 \mathrm{~h})$ & \\
1023 & $3.818 \times 10^{-8}$ & $8.399 \times 10^{-9}(0-7 \mathrm{~h})$ \\
& & $5.556 \times 10^{-9}(7-21 \mathrm{~h})$ \\
1173 & $3.153 \times 10^{-6}$ & $1.704 \times 10^{-6}(1-4 \mathrm{~h})$ \\
& & $3.781 \times 10^{-6}(5-17 \mathrm{~h})$ \\
\hline
\end{tabular}

constants has been analyzed according to Arrhenius equation:

$$
\log k_{\mathrm{p}}=\log A-0.434 \frac{E_{\mathrm{A}}}{R T},
$$

where $T$ is an absolute temperature $(\mathrm{K}), R$ is the molar gas constant $\left(8.3144 \mathrm{~J} \mathrm{~K}^{-1} \mathrm{~mol}^{-1}\right), E_{\mathrm{A}}$ is the activation energy, $A$ is the pre-exponential factor and $k_{\mathrm{p}}$ is the parabolic rate constant. Plot of logarithm of $k_{\mathrm{p}}$ versus reciprocal temperature is presented in Fig. 9. The data for bare steel fit a single line. The activation energy of the reaction is $232 \mathrm{~kJ} \mathrm{~mol}^{-1}$. The data for the boronized steel are presented in the same figure (Fig. 9). At 873-1023 K, relatively low rate constants have been found. At $1173 \mathrm{~K}$, rapid increase in the oxidation rate has been observed. These results indicate a change in the reaction mechanism with increasing temperature. The present data have been compared to the results from previous work [27]. A good agreement of parabolic rate constants has been found. At lower temperatures the activation energy has been estimated to be $93 \mathrm{~kJ} \mathrm{~mol}^{-1}$ (Table 6). This value is in agreement with previously published results $[27,36]$.
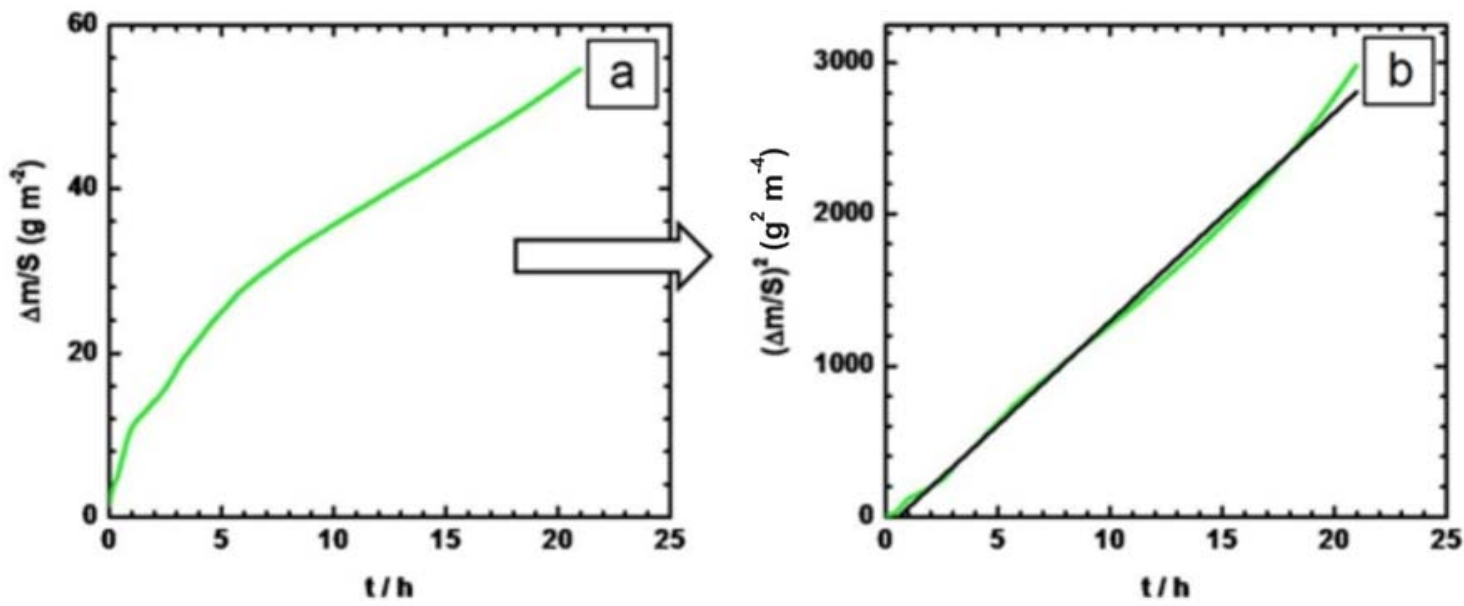

Fig. 8a,b. Parabolic plot of mass gain data. 
Table 6. Activation energies for oxidation of boride layers

\begin{tabular}{lc}
\hline & $E_{\mathrm{A}}\left(\mathrm{kJ} \mathrm{mol}^{-1}\right)$ \\
\hline Present data & 93 \\
Suwattannanont et al. $[27]$ & 97 \\
Shibuya et al. $[36]$ & 105 \\
\hline
\end{tabular}

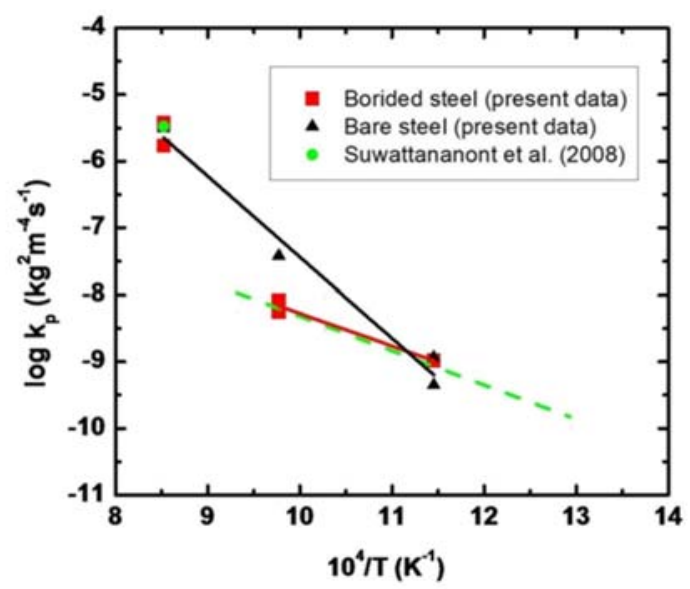

Fig. 9. Temperature dependence of parabolic rate constants.

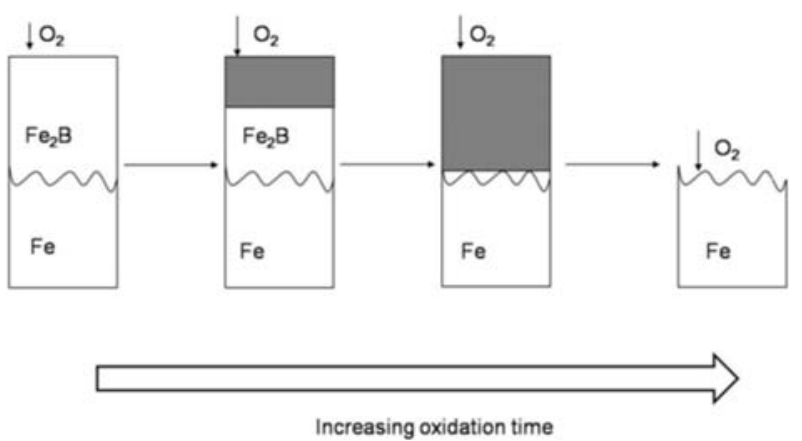

Fig. 10. Schematic of the oxidation mechanism.

The kinetic curve at $1173 \mathrm{~K}$ can be described by two successive parabolic periods followed by a near-linear behavior (Fig. 7c). This observation indicates that a protective scale has been initially formed on the surface. As the oxide thickness increased, the layer spalled off from the surface. As a result of oxide spallation, free access of oxygen occurred leading to reoxidation of the metal surface.

The suggested oxidation mechanism of the borided steel is presented in Fig. 10. At early oxidation stages, only a top layer of the boride coating has been oxidized. The oxide layer was initially adherent to the
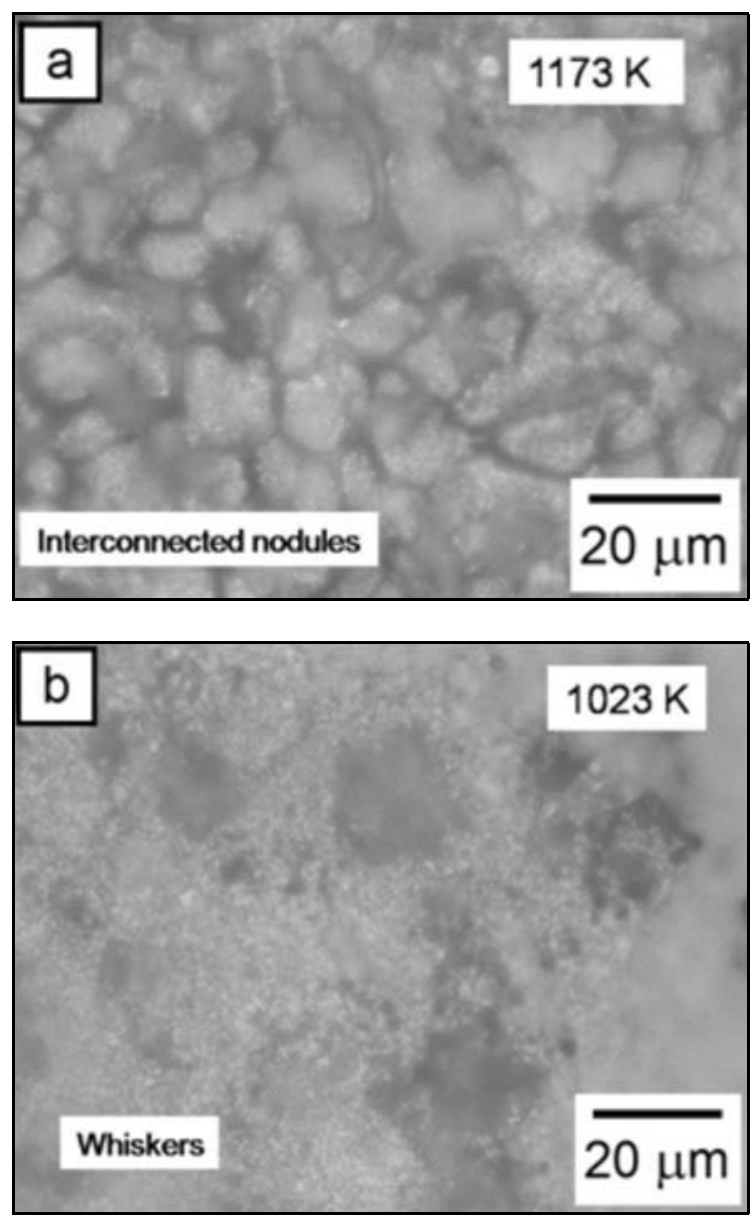

Fig. 11. Top views of oxidation products formed on steel substrate after annealing.

substrate and the oxidation followed the parabolic rate law. With an increasing oxidation time, however, the layer became thicker. As a result of the layer growth, large compressive stresses may have developed, leading to a localized spallation and scale cracking. After the first oxidation, some of the iron boride coating has remained (Fig. 10). As such, the re-oxidation of iron boride occurred, leading to a repetition of the previous step. At longer oxidation times, however, the iron boride coating has been fully consumed due to previous oxidation. This has left the bare metal for further oxidation leading to the linear oxidation behavior.

Top views of the oxide scales formed on unboronized low carbon steel are compared in Fig. 11. Two different microstructures can be observed. At temperatures lower than $1173 \mathrm{~K}$ the oxidation of the steel surface resulted in the formation of whiskers (Fig. 11b). The whiskers are known to relieve high residual stresses generated during oxidation [37]. The whisker-type oxides nucleate at dislocations generated by scale growth stresses. At $1173 \mathrm{~K}$, most of the surface area was covered with interconnected oxide nodules (Fig. 11a). This observation shows that the 

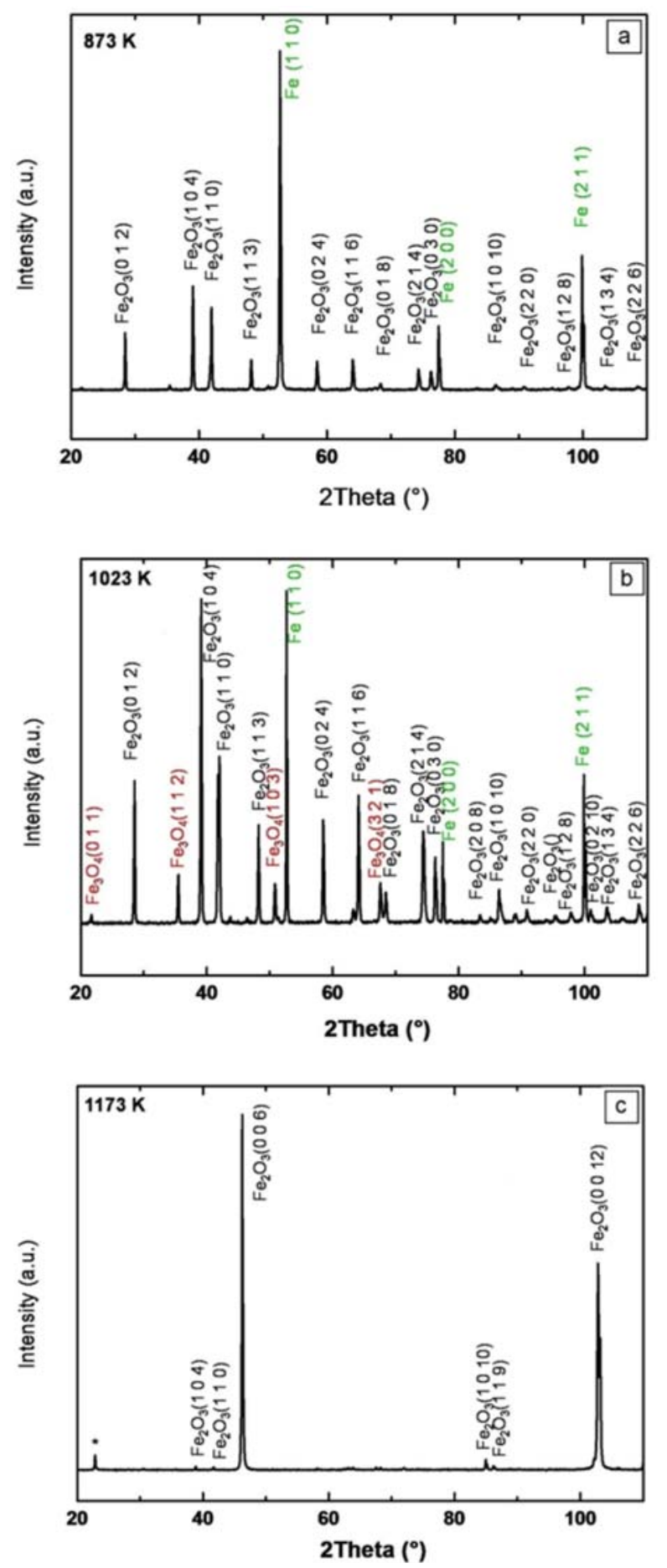

Fig. 12. Room temperature X-ray diffraction patterns of steel substrates after oxidation. The file numbers of the joint committee on powder diffraction standards (JCPDS) for the identified phases are the following: $\mathrm{Fe}_{2} \mathrm{O}_{3}$ (00-024-0072 at $873 \mathrm{~K}, 00-013-0534$ at $1023 \mathrm{~K}, 98-020-1097$ at $1173 \mathrm{~K}) ; \mathrm{Fe}$ (98-063-1729); $\mathrm{Fe}_{3} \mathrm{O}_{4}$ (98-008-5806). Asterisk $(*)$ indicates an unknown phase.

growth stresses generated during oxidation at high temperatures have been relieved by convolution or wrinkling of the oxide scale instead of dislocations. Since the scale grows in a confined space at the internal interface, the increase in volume due to oxide formation may generate large compressive stresses [35]. The large compressive stresses have probably resulted in de-cohesion and buckling of the oxidation product. This behavior has led to the scale spallation.

Further insight into high temperature oxidation behavior could be obtained by investigating the room temperature XRD patterns of the sample surface after TG. The X-ray diffraction patterns are compared in Figs. 12 and 13. In sample without boride layer, two different iron oxides have been observed $\left(\mathrm{Fe}_{2} \mathrm{O}_{3}\right.$ - hematite, $\mathrm{Fe}_{3} \mathrm{O}_{4}-$ magnetite, Fig. 12). In the boronized sample, diffraction peaks of different iron borates have been detected, next to $\mathrm{Fe}_{2} \mathrm{O}_{3}$ and $\mathrm{Fe}_{3} \mathrm{O}_{4}$ (Fig. 13). This observation confirms that the high temperature oxidation of the boronized samples was taking place and the iron boride phase has been oxidized.

The oxide scale of unboronized steel was composed of $\mathrm{Fe}_{2} \mathrm{O}_{3}$ and $\mathrm{Fe}_{3} \mathrm{O}_{4}$ in different amounts (Fig. 12). It has been reported that at lower temperatures $(<843 \mathrm{~K})$, the iron oxidation is dominated by $\mathrm{Fe}_{3} \mathrm{O}_{4}$ [38]. At higher temperatures $(>973 \mathrm{~K})$ the oxidation mechanism is mainly controlled by $\mathrm{FeO}$ layer formation [38]. Our results show that only $\mathrm{Fe}_{2} \mathrm{O}_{3}$ and $\mathrm{Fe}_{3} \mathrm{O}_{4}$ have been formed in the scale (Fig. 12). The wüstite phase $(\mathrm{FeO})$ could not be detected by XRD. One possible reason for its absence could be a relatively short oxidation time in our experiments. Another possible explanation could be related to the change in the local chemical equilibrium between iron oxides during their growth. If the scale is uniform and remains intact during oxidation, the layers grow by outward iron diffusion. However, if gaseous oxygen had an access to the metal-oxide interface, through cracks and other transport channels within the scale, the relative growth rates could be controlled by oxygen diffusion. Abuluwefa et al. observed that the scale composition of a mild steel at $1400 \mathrm{~K}$ changed with oxidation time [39]. The initially wüstite-rich scale became rich in $\mathrm{Fe}_{2} \mathrm{O}_{3}$ and $\mathrm{Fe}_{3} \mathrm{O}_{4}$ because of oxygen availability in the scale. In the present study, a preferred orientation of hematite in (006) direction at $1173 \mathrm{~K}$ has been found (Fig. 12c). The preferential orientation indicates that large compressive stresses have been developed in the scale, forcing the crystals to grow in the direction perpendicular to the original interface [35, 37]. A layer spallation has been observed. These observations indicate a possible accessibility of oxygen in the scale and at the scale-metal interface.

The oxide scale of boronized S235JRG1 has been found to be composed of different iron oxides and iron borates (Fig. 13, Table 7). The XRD data are compared in Fig. 13a,b,c. At $873 \mathrm{~K}$ the oxide scale of boronized S235JRG1 was mainly composed of hematite, magnetite and two different iron borates $-\mathrm{Fe}_{2} \mathrm{BO}_{4}$ 

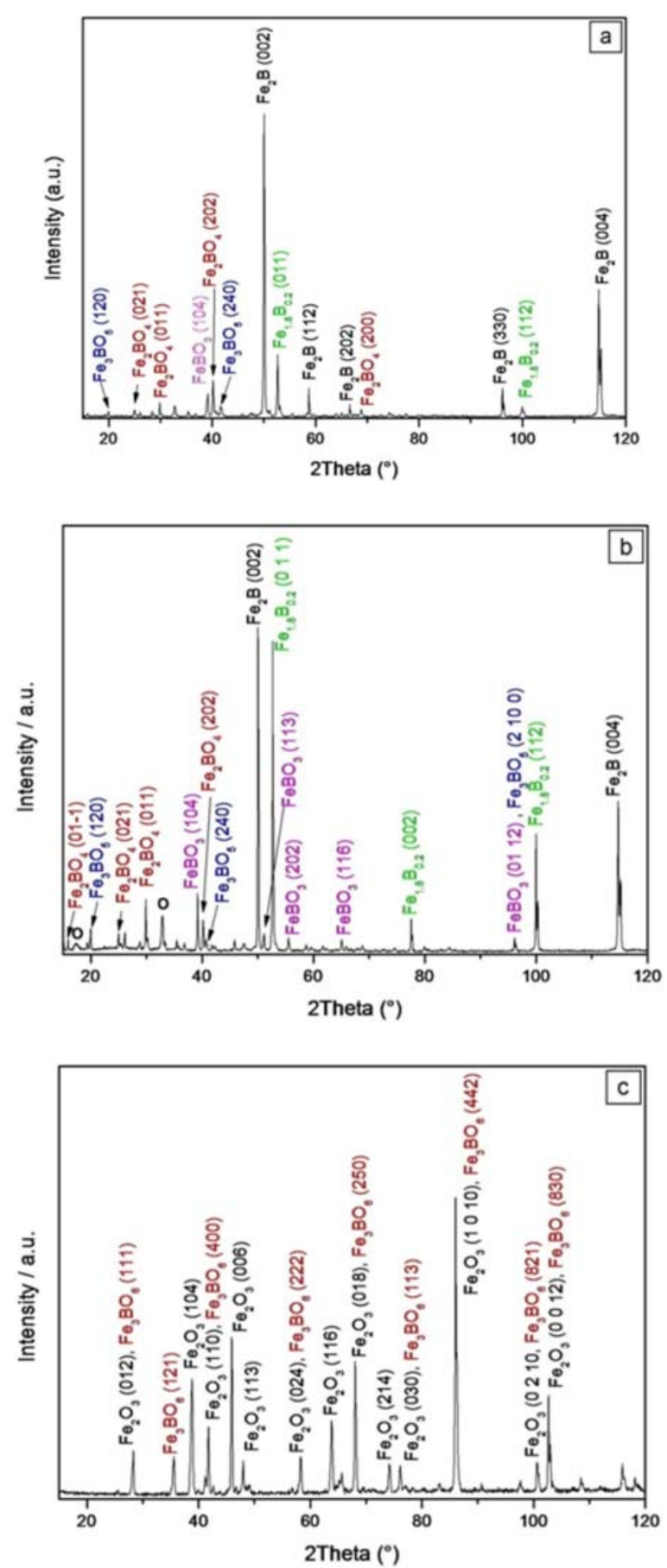

Fig. 13. Room temperature X-ray diffraction patterns of boronized S235JRG1 after oxidation. The JCPDS file numbers of the phases are the following: $\mathrm{Fe}_{1.8} \mathrm{~B}_{0.2}$ (98-061-3897), $\mathrm{Fe}_{2} \mathrm{~B}$ (98-061-3906 at $873 \mathrm{~K}, 00-003-1053$ at $1023 \mathrm{~K}) ; \mathrm{Fe}_{2} \mathrm{O}_{3}$ (98-016-1291), $\mathrm{Fe}_{2} \mathrm{BO}_{4}$ (98-008-6865); $\mathrm{FeBO}_{3}(98-003-4474) ; \mathrm{Fe}_{3} \mathrm{BO}_{5}$ (01-072-1314); $\mathrm{Fe}_{3} \mathrm{BO}_{6}(01-$ -070-0880). Circle (०) indicates an unknown phase.

and $\mathrm{FeBO}_{3}$ (Fig. 13a). Peaks of iron boride are also observed, indicating that the boride coating has been only partially oxidized at $873-1023 \mathrm{~K}$. At $1173 \mathrm{~K}$, peaks of $\mathrm{Fe}_{2} \mathrm{~B}$ have not been found in the XRD. The absence of $\mathrm{Fe}_{2} \mathrm{~B}$ signals indicates that this phase has been probably fully oxidized at this temperature.

Iron oxides have been formed in the course of iron boride oxidation according to the following equations:

$$
\begin{gathered}
\mathrm{FeB}+\frac{3+2 x}{4} \mathrm{O}_{2} \rightarrow \mathrm{FeO}_{x}+\frac{1}{2} \mathrm{~B}_{2} \mathrm{O}_{3}, \\
\mathrm{Fe}_{2} \mathrm{~B}+\frac{3+4 x}{4} \mathrm{O}_{2} \rightarrow 2 \mathrm{FeO}_{x}+\frac{1}{2} \mathrm{~B}_{2} \mathrm{O}_{3},
\end{gathered}
$$

where the different iron oxides have been written by a general formula $\mathrm{FeO}_{x}$, where $x=1.5$ stands for hematite and $x=\frac{4}{3}$ for magnetite. The equations indicate that $\mathrm{B}_{2} \mathrm{O}_{3}$ could have been formed in the course of oxidation. $\mathrm{B}_{2} \mathrm{O}_{3}$ has not been detected by XRD in the present case. This could be related to the noncrystalline ("glassy") nature of this phase [40].

Different iron borates, observed in the scale at 873 $1123 \mathrm{~K}$, are probably formed by a direct oxidation of iron boride according to the following equations:

$$
\begin{gathered}
\mathrm{FeB}+\frac{3}{2} \mathrm{O}_{2} \rightarrow \mathrm{FeBO}_{3}, \\
\mathrm{Fe}_{2} \mathrm{~B}+2 \mathrm{O}_{2} \rightarrow \mathrm{Fe}_{2} \mathrm{BO}_{4} .
\end{gathered}
$$

Alternatively, the formation of iron borates can also be explained by a reaction of some portion of $\mathrm{B}_{2} \mathrm{O}_{3}$ with $\mathrm{Fe}_{2} \mathrm{O}_{3}$ and/or $\mathrm{Fe}_{3} \mathrm{O}_{4}$ according to the following reactions:

$$
\begin{gathered}
\mathrm{FeB}+\frac{3+2 x}{4} \mathrm{O}_{2} \rightarrow \mathrm{FeO}_{x}+\frac{1}{2} \mathrm{~B}_{2} \mathrm{O}_{3}, \\
\mathrm{Fe}_{2} \mathrm{O}_{3}+\mathrm{B}_{2} \mathrm{O}_{3} \rightarrow 2 \mathrm{FeBO}_{3}, \\
3 \mathrm{Fe}_{2} \mathrm{O}_{3}+\mathrm{B}_{2} \mathrm{O}_{3} \rightarrow 2 \mathrm{Fe}_{3} \mathrm{BO}_{6}, \\
\mathrm{Fe}_{3} \mathrm{O}_{4}+\frac{1}{2} \mathrm{Fe}_{2} \mathrm{O}_{3}+\mathrm{B}_{2} \mathrm{O}_{3} \rightarrow 2 \mathrm{Fe}_{2} \mathrm{BO}_{4}+\frac{1}{4} \mathrm{O}_{2}, \\
7 \mathrm{Fe}_{3} \mathrm{O}_{4}+3 \mathrm{Fe}+4 \mathrm{~B}_{2} \mathrm{O}_{3} \rightarrow 8 \mathrm{Fe}_{3} \mathrm{BO}_{5} .
\end{gathered}
$$

The protective effect of the scale at $873-1023 \mathrm{~K}$ is probably related to the presence of different iron borates in the scale. $\mathrm{FeBO}_{3}$ and $\mathrm{Fe}_{3} \mathrm{BO}_{6}$ are stable phases in the pseudo-binary $\mathrm{Fe}_{2} \mathrm{O}_{3}-\mathrm{B}_{2} \mathrm{O}_{3}$ phase diagram [41]. $\mathrm{FeBO}_{3}$ transforms into $\mathrm{Fe}_{3} \mathrm{BO}_{6}$ and $\mathrm{B}_{2} \mathrm{O}_{3}$ at $1073 \mathrm{~K}$ [41]. $\mathrm{Fe}_{3} \mathrm{BO}_{6}$ transforms into $\mathrm{Fe}_{2} \mathrm{O}_{3}$ and $\mathrm{B}_{2} \mathrm{O}_{3}$ at $\sim 1180 \mathrm{~K}$ [41]. $\mathrm{Fe}_{2} \mathrm{BO}_{4}$ is a phase reported to occur in the $\mathrm{FeO}-\mathrm{B}_{2} \mathrm{O}_{3}$ pseudo-binary phase diagram [42]. $\mathrm{Fe}_{2} \mathrm{BO}_{4}$ is mixed valence $\left(\mathrm{Fe}^{3+} / \mathrm{Fe}^{2+}\right)$ iron borate $[43,44]$. This compound has been observed in oxide scales developed on boronized pure iron during 
Ta b l e 7. Oxides identified in the scale of boronized S235JRG1

\begin{tabular}{rcccccc}
\hline$T(\mathrm{~K})$ & $\mathrm{Fe}_{2} \mathrm{O}_{3}$ & $\mathrm{Fe}_{3} \mathrm{O}_{4}$ & $\mathrm{FeBO}_{3}$ & $\mathrm{Fe}_{3} \mathrm{BO}_{6}$ & $\mathrm{Fe}_{2} \mathrm{BO}_{4}$ & $\mathrm{Fe}_{3} \mathrm{BO}_{5}$ \\
\hline 873 & $\mathrm{X}$ & $\mathrm{X}$ & $\mathrm{X}$ & & $\mathrm{X}$ & $\mathrm{X}$ \\
1023 & $\mathrm{X}$ & $\mathrm{X}$ & $\mathrm{X}$ & $\mathrm{X}$ & $\mathrm{X}$ \\
1173 & & & & & \\
\hline
\end{tabular}

oxidation at high temperatures (>973 K, $[45,46])$. $\mathrm{Fe}_{2} \mathrm{BO}_{4}$ forms non-coherent, granular, blocking layer acting along the scale/metal interface $[45,46]$. The protective effect of this phase is attributed to a decrease of interfacial area for iron diffusion from the metal substrate [46].

Previous studies suggest that the iron boride oxidation is dominated by $\mathrm{B}_{2} \mathrm{O}_{3}$ formation [27-29]. This phase formation is observed to take place at temperatures of $773-873 \mathrm{~K}$ [27]. $\mathrm{B}_{2} \mathrm{O}_{3}$ melts and covers the sample surface. The presence of liquid $\mathrm{B}_{2} \mathrm{O}_{3}$ could be efficient in retarding the oxidation kinetics as this phase can act as a protective diffusion barrier over the substrate [30]. $\mathrm{B}_{2} \mathrm{O}_{3}$ has not been detected by XRD in the present study, probably due to its non-crystalline nature. In this respect, it is worth mentioning that this phase evaporates at temperatures above $1073 \mathrm{~K}$ [27]. Therefore, the effect of this phase on the oxidation behavior at $1173 \mathrm{~K}$ can be expected to be minimal.

The XRD results show that the scale formed at $1173 \mathrm{~K}$ has been composed of $\mathrm{Fe}_{3} \mathrm{BO}_{6}$ and $\mathrm{Fe}_{2} \mathrm{O}_{3}$ (Fig. 13c). The amount of $\mathrm{Fe}_{3} \mathrm{BO}_{6}$ was relatively small. The amount of this phase is expected to further decrease with increasing oxidation time since $\mathrm{Fe}_{3} \mathrm{BO}_{6}$ transforms into $\mathrm{Fe}_{2} \mathrm{O}_{3}$ and $\mathrm{B}_{2} \mathrm{O}_{3}$ at $\sim 1180 \mathrm{~K}$ according to the $\mathrm{Fe}_{2} \mathrm{O}_{3}-\mathrm{B}_{2} \mathrm{O}_{3}$ phase diagram [41]. $\mathrm{Fe}_{2} \mathrm{O}_{3}$ forms a buckling scale due to large internal stresses (Fig. 11). The parabolic rate constants of borided steel at $1173 \mathrm{~K}$ are comparable to those of the bare steel (Fig. 9). At $1173 \mathrm{~K}$, the oxide scale of the bare steel has been composed of $\mathrm{Fe}_{2} \mathrm{O}_{3}$ (Fig. 12c). These results indicate that the high oxidation rates of boronized steel at $1173 \mathrm{~K}$ are related to $\mathrm{Fe}_{2} \mathrm{O}_{3}$ formation in the scale.

The presence of $\mathrm{Fe}_{2} \mathrm{O}_{3}$ in the scale is probably related to a gradual transformation of $\mathrm{Fe}_{3} \mathrm{BO}_{6}$ into $\mathrm{Fe}_{2} \mathrm{O}_{3}$ and $\mathrm{B}_{2} \mathrm{O}_{3}$. The high growth rates at $1173 \mathrm{~K}$ could be related to the change in the local chemical equilibrium between $\mathrm{Fe}_{2} \mathrm{O}_{3}$ and $\mathrm{Fe}_{3} \mathrm{BO}_{6}$ during oxidation. It can be expected that the local chemical equilibrium between these oxides has changed during their growth and portion of $\mathrm{Fe}_{2} \mathrm{O}_{3}$ in the scale has increased with increasing oxidation time. The $\mathrm{Fe}_{2} \mathrm{O}_{3}$ scale is non-protective. This scale is expected to spall off at longer annealing times.

Iron oxides are nonstoichiometric compounds due to large populations of point defects, such as oxygen or metal vacancies [35]. The large defect populations may lead to an enhanced ionic diffusion, especially at high temperatures. It has been previously found that the oxygen supply may affect the population of defects in the scale and thereby increase the growth rate of hematite [38]. $\mathrm{Fe}_{2} \mathrm{O}_{3}$ is a slightly oxygen-deficit compound [35]. It can be written as $\mathrm{Fe}_{2} \mathrm{O}_{3-x}$. This phase may grow by inward oxygen diffusion. In fact, the iron diffusion coefficients in $\mathrm{Fe}_{2} \mathrm{O}_{3}$ are smaller than oxygen diffusion coefficients at $1173 \mathrm{~K}$ [35]. Furthermore, the $\mathrm{Fe}_{2} \mathrm{O}_{3}$ scale is porous and easily spalls off from the substrate. The availability of oxygen molecules in the porous scale can be expected to be very high. If gaseous oxygen had an access to the boride-oxide interface, the growth rates could be controlled by oxygen diffusion instead of iron diffusion. Further exploration of these aspects is required.

\section{Conclusion}

In the present work, the microstructure, chemical composition and high temperature oxidation resistance of boride coatings have been investigated. The boride layers were prepared by powder-pack boronizing by using a Durborid ${ }^{\circledR}$ powder. The substrates of low carbon steel S235JRG1 were boronized at $1273 \mathrm{~K}$ for $45-150 \mathrm{~min}$. The layers with an average thickness of $76-123 \mu \mathrm{m}$ were produced. The layers had a distinct tooth-like microstructure. The major component was $\mathrm{Fe}_{2} \mathrm{~B}$. The amount of $\mathrm{FeB}$ was small and this phase was preferentially located on the sample surface.

The oxidation resistance of the bare steel and boride coating was investigated by simultaneous thermal analysis in flowing synthetic air. At $873-1173 \mathrm{~K}$, a parabolic oxidation of the boride layer has been observed. The iron boride layer oxidation is a thermally activated process. The boride coating is protective against oxidation at temperatures below $1173 \mathrm{~K}$. At $1173 \mathrm{~K}$, two successive parabolic periods have been found, followed by a breakaway oxidation behavior. The protective effect of the coating is related to the formation of different iron borates in the scale. At $1173 \mathrm{~K}$, the scale was mainly composed of $\mathrm{Fe}_{2} \mathrm{O}_{3}$ and $\mathrm{Fe}_{3} \mathrm{BO}_{6}$. The local chemical equilibrium between $\mathrm{Fe}_{2} \mathrm{O}_{3}$ and $\mathrm{Fe}_{3} \mathrm{BO}_{6}$ changes during the layer growth since $\mathrm{Fe}_{2} \mathrm{O}_{3}$ may grow by gradual transformation of $\mathrm{Fe}_{3} \mathrm{BO}_{6}$. The $\mathrm{Fe}_{2} \mathrm{O}_{3}$ scale is nonprotective and spalls off from the substrate. Oxygen diffusion through the porous $\mathrm{Fe}_{2} \mathrm{O}_{3}$ scale is expected to be high. The oxygen availability in the 
scale may affect the reaction mechanism and further increase the reaction rate at longer oxidation times.

\section{Acknowledgements}

This work was supported by the European Regional Development Fund (ERDF) via agreements ITMS:2622012 0014 and ITMS:26220120048 "Centre for development and application of advanced diagnostic methods in processing of metallic and non-metallic materials" and the Grant Agency VEGA of the Slovak Ministry of Education, Science, Research and Sport via project No. 1/0068/14.

\section{References}

[1] Allaoui, O., Bouaouadja, N., Saindernan, G.: Surf. Coat. Technol., 201, 2006, p. 3475. doi:10.1016/j.surfcoat.2006.07.238

[2] Meléndez, E., Campos, I., Rocha, E., Barrón, M. A.: Mater. Sci. Eng. A, 234-236, 1997, p. 900. doi:10.1016/S0921-5093(97)00389-4

[3] Tsipas, D. N., Rus, J.: J. Mater. Sci. Lett., 6, 1987, p. 118. doi:10.1007/BF01729451

[4] Ozbek, I., Bindal, C.: Surf. Coat. Technol., 154, 2002, p. 14. doi:10.1016/S0257-8972(01)01409-8

[5] Mu, D., Yang, C., Shen, B. I., Jiang, H.: J. Alloy Compd., 479, 2009, p. 629. doi:10.1016/j.jallcom.2009.01.015

[6] Mu, D., Shen, B. I.: Int. J. Refractory Metal Hard Mater., 28, 2010, p. 424. doi:10.1016/j.ijrmhm.2010.01.003

[7] Yokota, H., Kudoh, T., Suzuki, T.: Surf. Coat. Technol., 169-170, 2003, p. 171. doi:10.1016/S0257-8972(03)00221-4

[8] Dokumaci, E., Ozkan, I., Ozyigit, M. B., Önay, B.: Int. J. Refractory Metal Hard Mater., 41, 2013, p. 276. doi:10.1016/j.ijrmhm.2013.04.014

[9] Jiang, J., Wang, Y., Zhong, Q., Zhou, Q., Zhang, L.: Surf. Coat. Technol., 206, 2011, p. 473. doi:10.1016/i.surfcoat.2011.07.053

[10] Béjar, M. A., Moreno, E.: J. Mater. Process. Technol., 173, 2006, p. 352. doi:10.1016/j.jmatprotec.2005.12.006

[11] Meric, C., Sahin, S., Backir, B., Koksal, N. S.: Mater. Design, 27, 2006, p. 751. doi:10.1016/j.matdes.2005.01.018

[12] Venkataraman, B., Sundararajan, G.: Surf. Coat. Technol., 73, 1995, p. 177. doi:10.1016/0257-8972(94)02379-4

[13] Martini, C., Palombarini, G., Poli, G., Prandstraller, D.: Wear, 256, 2004, p. 608. doi:10.1016/j.wear.2003.10.003

[14] Atik, E., Yunker, U., Meric, C.: Tribology International, 36, 2003, p. 155. doi:10.1016/S0301-679X(02)00069-5

[15] Tsipas, D. N., Triantafyllidis, G. K., Kipkemoi, J., Flitris, Y.: Mater. Manufact. Processes, 14, 1999, p. 697. doi:10.1080/10426919908914863
[16] Kariofillis, G. K., Kiourtsidis, G. E., Tsipas, D. N.: Surf. Coat. Technol., 201, 2006, p. 19. doi:10.1016/j.surfcoat.2005.10.025

[17] Kayali, Y., Anaturk, B.: Mater. Design, 46, 2013, p. 776. doi:10.1016/i.matdes.2012.11.040

[18] Campos, I., Palomar-Pardave, M., Amador, A., Villa Velazques, C., Hadad, J.: Appl. Surf. Sci., 253, 2007, p. 9061. doi:10.1016/j.apsusc.2007.05.016

[19] Jankura, D., Brezinová, J., Sevčíková, J., Draganovská, D., Guzanová, A.: Materials in Engineering and Manufacturing Technology to their Finalization. Košice, Vydavatel'stvo Technickej Univerzity v Košiciach 2011. ISBN 978-80-553-0786-2 (in Slovak).

[20] Sista, V., Kahvecioglu, O., Eryilmaz, O. L., Erdemir, A., Timur, S.: Thin Solid Films, 520, 2011, p. 1582. doi:10.1016/j.tsf.2011.07.057

[21] Jurči, P., Hudáková, M.: J. Mater. Eng. Perform., 20, 2011, p. 1180. doi:10.1007/s11665-010-9750-x

[22] Jurči, P., Hudáková, M., Kusý, M.: Kovove Mater., 50, 2012, p. 177.

[23] Keddam, M., Chentouf, S. M.: Appl. Surf. Sci., 252, 2005, p. 393. doi:10.1016/j.apsusc.2005.01.016

[24] Campos-Silva, I., Ortiz-Dominguez, M., Bravo-Barcenas, O., Donu-Ruiz, M. A., Bravo-Barcenas, D., TapiaQuintero, C., Jimenez-Reyes, M. Y.: Surf. Coat. Technol., 205, 2010, p. 403. doi:10.1016/j.surfcoat.2010.06.068

[25] Campos-Silva, I.: JESTECH, 15, 2012, p. 53.

[26] Yan, P. X., Zhang, X. M., Xu, J. W., Wu, Z. G., Song, Q. M.: Mater. Chem. Phys., 71, 2001, p. 107. doi:10.1016/S0254-0584(01)00270-X

[27] Suwattananont, N., Petrova, R. S.: Oxid. Metals, 70, 2008, p. 307. doi:10.1007/s11085-008-9123-0

[28] Petrova, R. S., Suwattananont, N., Samardzic, V.: J. Mater. Eng. Perform., 17, 2008, p. 340. doi:10.1007/s11665-008-9228-2

[29] Petrova, R. S., Suwattananont, N.: J. Electron. Mater., 34, 2005, p. 575. doi:10.1007/s11664-005-0068-7

[30] Dokumaci, E., Özkan, I., Onay, B.: Surf. Coat. Technol., 232, 2013, p. 22. doi:10.1016/j.surfcoat.2013.04.047

[31] Hudáková, M., Jurči, P., Sedlická, V.: In: Proceedings of 21st International Conference on Metallurgy and Materials: Metal 2012. Brno, Tanger s.r.o. 2012, p. 939.

[32] Martini, C., Palombarini, G., Carbucichio, M.: J. Mater. Sci., 39, 2004, p. 933. doi:10.1023/B:JMSC.0000012924.74578.87

[33] Palombarini, G., Carbucicchio, M.: J. Mater. Sci. Lett., 3, 1984, p. 791. doi:10.1007/BF00727975

[34] Sahin, S.: J. Mater. Process. Technol., 209, 2009, p. 1736. doi:10.1016/j.jmatprotec.2008.04.040

[35] Sarrazin, P., Galerie, A., Fouletiers, J.: Mechanisms of High Temperature Corrosion - A Kinetic Approach. Zürich, Trans Tech Publications Ltd. 2008.

[36] Shibuya, Y., Endo, T.: The Iron and Steel Institute of Japan, 64, 1978, p. 1396.

[37] Lee, D. H., Lee, D. B., Jung, W. S.: J. Ceram. Process. Res., 7, 2006, p. 140.

[38] Chen, R. Y., Yuen, W. Y. D.: Oxid. Metals, 59, 2003, p. 433. doi:10.1023/A:1023685905159 
[39] Abuluwefa, H., Root, J. H., Guthrie, R. I. L., Ajersch, F.: Metall. Mater. Trans. B, 27, 1996, p. 993. doi:10.1007/s11663-996-0014-y

[40] Mozzi, R. L., Warren, B. E.: J. Appl. Cryst., 3, 1970, p. 251. doi:10.1107/S0021889870006143

[41] Makram, H., Touron, L., Loriers, J.: J. Crystal Growth, 13-14, 1972, p. 585. doi:10.1016/0022-0248(72)90522-2

[42] Available at http://www.crct.polymtl.ca/fact/ documentation/TDNucl/BO1.5-FeO.jpg (accessed 2 Sept 2014).
[43] Attfield, J. P., Clarke, J. F., Perkins, D. A.: Physica B, 180-181, 1992, p. 581. doi:10.1016/0921-4526(92)90401-D

[44] Shimomura, S., Nakamura, S., Ikeda, N., Kaneko, E., Kato, K., Kohn, K.: J. Magnetism Magnetic Mater., 310, 2007, p. 793. doi:10.1016/j.jmmm.2006.10.184

[45] Pons, M., Galerie, A., Caillet, M.: J. Mater. Sci., 21, 1986, p. 2697. doi:10.1007/BF00551475

[46] Rolls, R., Shaw, R. D.: Corrosion Sci., 14, 1974, p. 431. $\underline{\text { doi:10.1016/0010-938X(74)90003-1 }}$ 